\title{
New Strategies for Overcoming Limitations of Mesenchymal Stem Cell-Based Immune Modulation
}

\author{
Nayoun Kim ${ }^{1,2}$, Seok-Goo Cho ${ }^{1,2,3}$ \\ ${ }^{1}$ Institute for Translational Research and Molecular Imaging, The Catholic University of Korea College of Medicine, Seoul, ${ }^{2}$ Laboratory \\ of Immune Regulation, Convergent Research Consortium for Immunologic Disease, Seoul, ${ }^{3}$ Catholic Blood and Marrow Transplantation \\ Center, Seoul St. Mary's Hospital, The Catholic University of Korea College of Medicine, Seoul, Korea
}

Mesenchymal stem cells (MSCs) have rapidly been applied in a broad field of immune-mediated disorders since the first successful clinical use of MSCs for treatment of graft-versus-host disease. Despite the lack of supporting data, expectations that MSCs could potentially treat most inflammatory conditions led to rushed application and development of commercialized products. Today, both pre-clinical and clinical studies present mixed results for MSC therapy and the discrepancy between expected and actual efficacy of MSCs in various diseases has evoked a sense of discouragement. Therefore, we believe that MSC therapy may now be at a critical milestone for re-evaluation and re-consideration. In this review, we summarize the current status of MSC-based clinical trials and focus on the discrepancy between expected and actual outcome of MSC therapy from bench to bedside. Importantly, we discuss the underlying limitations of MSCs and suggest a new guideline for MSC therapy in hopes of improving their therapeutic efficacy.

Keywords: Mesenchymal stem cells, Immune modulation, Clinical trial, Limitation

\section{Introduction}

Mesenchymal stem cells (MSCs) are self-renewing multipotent progenitor cells with multi-lineage potential to differentiate into other cell types of mesodermal origin. The International Society for Cellular Therapy established the minimal criteria for MSCs, which defines MSCs as

\footnotetext{
Accepted for publication May 4, 2015, Published online May 30, 2015 Correspondence to Seok-Goo Cho

Department of Hematology, Catholic Blood and Marrow Transplantation Center; Laboratory of Immune Regulation, Convergent Research Consortium for Immunologic disease (CRCID); Institute for Translational Research and Molecular Imaging, Seoul St. Mary's Hospital, The Catholic University of Korea College of Medicine, \#505, Banpo-dong, Seocho-gu, Seoul 137-040, Korea Tel: +82-2-2258-6052, Fax: +82-2-599-3589

E-mail: chosg@catholic.ac.kr

(c) This is an open-access article distributed under the terms of the Creative Commons Attribution Non-Commercial License (http://creativecommons.org/ licenses/by-nc/4.0/), which permits unrestricted non-commercial use, distribution, and reproduction in any medium, provided the original work is properly cited.
}

plastic-adherent cells that express specific cell-surface molecules (CD105+, CD73+, CD90+, CD11b-, CD79a-, CD19 and human leukocyte antigen (HLA)-DR-) and have the ability to differentiate into osteoblasts, adipocytes, and chondroblasts under standard in vitro conditions (1). MSCs have created growing interest in various fields of medicine due to their unique properties including differentiation and regenerative potential, immune modulation and migration toward sites of inflammation (2). While MSCs were initially used for tissue repair and regenerative medicine, discovery of immune-modulating mechanisms of MSCs have prompted their use in immune disorders. Currently, the therapeutic potential of MSCs has been investigated in numerous immune-mediated conditions in both pre-clinical and clinical studies, including graft-versus-host disease (GVHD), cardiovascular diseases, and chronic inflammatory autoimmune diseases.

Contrary to initial expectations, however, MSCs have failed to demonstrate clear efficacy in recent trials. Therefore, a critical evaluation of MSC therapy is needed at this point in research and development. In this review, 
we highlight the immunomodulatory properties of MSCs that contribute to their therapeutic potential. We summarize the current status of MSC-based clinical trials and focus on the discrepancy between expected and actual outcomes of MSCs from bench to bedside. Finally, we discuss the underlying limitations of MSCs and suggest a new guideline for MSC therapy to improve their therapeutic efficacy.

\section{Immunomodulatory properties of MSCs}

The rationale of MSCs as a novel therapeutic approach in a wide variety of disorders is based on their potent immunosuppressive and anti-inflammatory effects. MSCs interact with various lymphocytes and play a regulatory role in both the innate and adaptive immune system. MSC-based immune modulation primarily occurs through paracrine effects by production of soluble factors, including transforming growth factor- $\beta$ (3-5), hepatocyte growth factor (HGF) (6), nitric oxide (NO) (7), hemoxygenase (HO) (8), interleukin (IL)-6 (9-11), prostaglandin E2 (PGE2) (5, 12-16) and indoleamine 2, 3-dioxygenase (IDO) (15, 17), but may also occur through direct cell-to cell contact (4, $16,18,19)$. The immunomodulatory properties of MSCs are summarized in Table 1.

Within the innate immune system, MSCs are able to inhibit the activation of pro-inflammatory monocytes and macrophages $(14,20)$. At the same time, monocytes and macrophages may acquire anti-immunosuppressive func- tions, in the presence of MSCs and their soluble factors. Classical M1 macrophages, which possess pro-inflammatory functions become alternatively activated into anti-inflammatory M2 macrophages, which are characterized by high expression of interleukin (IL)-10 and low levels of tumor necrosis factor (TNF) and interferon (IFN)- $\gamma$ production $(21,22)$. Furthermore, MSCs inhibit the differentiation of monocytes into fully mature dendritic cells (DCs) $(9,10,12,13,23-25)$. DCs generated in the presence of MSCs are characterized by semi-mature phenotype, in which the DC maturation markers and co-stimulatory molecules are down regulated. These tolerogenic DCs produce high levels of IL-10 and have reduced ability to stimulate allogeneic T-cell proliferation in a mixed lymphocyte reaction. Also, MSCs inhibit proliferation and cytotoxicity of natural killer (NK) cells mediated mainly through PGE2 and IDO production and often requires cell to cell contact $(4,15)$.

In the adaptive immune system, MSCs are able to suppress T-cell proliferation through the secretion of various soluble factors $(3,6-8,17)$ and can also inhibit T-cell activation through cell-to-cell contact (18). Importantly, MSCs are able to modulate the T-cell response by orchestrating the balance between the pro-inflammatory and anti-inflammatory profiles. In an environment that consists of strong inflammatory components, MSCs are able to shift the pro-inflammatory Thl profile to an anti-inflammatory Th2 profile $(26,27)$. MSCs also modulate Th17 cell subsets by preventing the differentiation of naïve Th0 cells

Table 1. Immunomodulatory effects of mesenchymal stem cells

\begin{tabular}{|c|c|c|c|}
\hline & Cell Subset & Effects & Potential mechanism \\
\hline \multirow[t]{5}{*}{$\begin{array}{l}\text { Innate } \\
\text { immunity }\end{array}$} & Monocytes & $\begin{array}{l}\text {-Induce anti-immunosuppressive functions } \\
\text {-Inhibit differentiation to mature dendritic cells }\end{array}$ & Through IL-6, PGE2, TGF- $\beta$, HGF production \\
\hline & Macrophages & -Inhibit pro-inflammatory M1 macrophages & Through IL-6, PGE2, TGF- $\beta$, HGF production \\
\hline & & $\begin{array}{l}\text {-Alternatively activate anti-inflammatory M2 macro } \\
\text { phages }\end{array}$ & \\
\hline & NK cells & $\begin{array}{l}\text {-Inhibit proliferation } \\
\text {-Inhibit cytotoxicity }\end{array}$ & $\begin{array}{l}\text { Through TGF- } \beta \text {, PGE2, IDO production and direct } \\
\text { cell-to cell contact }\end{array}$ \\
\hline & $\begin{array}{l}\text { Dendritic } \\
\text { cells }\end{array}$ & $\begin{array}{l}\text {-Induce semi-mature tolerogeneic DCs with reduced } \\
\text { ability to stimulate allogeneic response }\end{array}$ & Through IL-6, PGE2, TGF- $\beta$, HGF production \\
\hline \multirow[t]{3}{*}{$\begin{array}{l}\text { Adaptive } \\
\text { immunity }\end{array}$} & $\mathrm{T}$ cells & $\begin{array}{l}\text {-Suppress T-cell proliferation } \\
\text {-Modulate inflammatory profile of helper T cells } \\
\text {-Induce regulatory T cells }\end{array}$ & $\begin{array}{l}\text { Through PGE2, TGF- } \beta, \mathrm{HGF}, \mathrm{NO}, \mathrm{HO} \text {, IDO } \\
\text { production and direct cell-to cell contact }\end{array}$ \\
\hline & B cells & $\begin{array}{l}\text {-Inhibit B-cell proliferation } \\
\text {-Inhibit plasma cell differentiation induced by allosti } \\
\text { mulation }\end{array}$ & $\begin{array}{l}\text { Through direct cell-to cell contact and arrest of cell } \\
\text { cycle G0/G1 }\end{array}$ \\
\hline & & -Inhibit Ig production & \\
\hline
\end{tabular}

DC: dendritic cell; HGF: hepatocyte growth factor; HO: hemoxygenase; IDO: indoleamine 2,3-dioxygenase; Ig: immunoglobulin; IL: interleukin; NO: nitric oxide; PGE2: prostaglandin E2; TGF- $\beta$ : transforming growth factor- $\beta$. 
to Th17 cells and by suppressing the production of Th17 cytokines, including IL-17 and IL-22 (16, 28). In addition, MSCs can induce the differentiation of CD4+ helper $\mathrm{T}$ cells (Th0) into regulatory $\mathrm{T}$ cells (Tregs), a unique subpopulation of $\mathrm{T}$ cells that are specialized in suppressing immune responses. The coculture of MSCs with peripheral blood mononuclear cells (PBMCs) induces the differentiation of Foxp3 + Tregs through PGE2 and TGF- $\beta$ (5, 29). Moreover, MSCs-induced Tregs demonstrated potent inhibitory functions against alloreactive T-cell proliferation in vitro.

While the effects of MSCs on B cells remain contradictory, there is evidence that MSCs have close interactions with B cells (30). MSCs are able to inhibit B-cell proliferation through cell-to-cell contact and by arrest of cell cycle G0/G1 (19, 31). Furthermore, MSCs inhibit plasma cell differentiation induced by allostimulation (32) and Ig production (33). Studies have also suggested that while MSCs are able to suppress B cells activated under various stimuli, MSCs are unable to modulate naïve or memory B cells that do not require such signals (34).

\section{Overview of MSC-based therapies in clinical practice}

Along with the initial reports on in vitro and in vivo immunosuppressive functions of MSCs (35), the first successful clinical application of MSCs to treat GVHD triggered an explosive interest in numerous research groups (36). Since the first clinical use in 2004, over 480 MSC-based clinical trials worldwide are listed in the clinical trial registry of the U.S. National Institutes of Health and more than 50 publications on MSC therapy have been reported for the treatment of at least 10 different target diseases (Table 2). The validation of safety of MSCs from different donor sources in clinical trials encouraged the commercialization of MSC products. In 2005, Osiris Therapeutics, Inc developed the first off-the shelf MSC product, Prochymal, using the bone marrow of healthy donors. In 2012, Prochymal received FDA-approval in Canada and New Zealand as a first-line treatment for acute GVHD in pediatric patients. In Korea, the first FDA approval of MSC product came in 2011 when Hearticellgram-AMI developed by Pharmicell was approved for treatment of myocardial infarctions. Subsequently, in 2012 two more mesenchymal stem cell products (Cartistem developed by Medipost for knee cartilage regeneration and Cupistem developed by Anterogen for Crohn's disease) were approved by the Korean FDA (37).

Although the initial expectations for MSC-based thera- pies led to the wide clinical application and rapid development of commercialized products, the therapeutic efficacy have been unsatisfactory. Series of phase I/II clinical trials using MSCs produced ambiguous results and yet further large-scale randomized trials were continued. The underlying foundation of MSC-based therapy built on uncertain clinical data led to weak clinical outcomes in the randomized placebo-controlled phase III trials of MSC products reported by Osiris Therapeutics, Inc for both acute myocardial infarction (38) and steroid-refractory GVHD (39). In addition, outcomes of Korean MSC-products have yet to publish official results in peer-reviewed journals since their FDA approval.

The contradicting clinical outcomes may be a major setback to the entire MSC field. However, we believe that MSC-based therapy, now more than ever, need thorough analysis and reconsideration in the hopes of overcoming their limitations in future studies.

\section{Discrepancy between expected and actual results of MSC efficacy from bench to bedside}

Despite the considerable progress that has been made in the development of MSC therapy for various diseases, studies have produced mixed results regarding their therapeutic efficacy. Below we describe the discrepancy between expected and actual results of MSCs from both pre-clinical and clinical studies (summarized in Table 2).

\section{Graft-versus-host disease}

Graft-versus-host disease (GVHD) is a major complication associated with morbidity and mortality following allogeneic hematopoietic stem cell transplantation (HSCT) characterized by dysregulation of inflammatory cytokines and activated donor cells that attack recipient organs and tissues. In the pilot study using MSCs for GVHD, Le Blanc et al. reported the successful use of third-party MSCs to treat steroid-refractory GVHD following allogeneic stem cell transplantation (36). This initial study provided a rationale for the use of MSCs in GVHD and encouraged further pre-clinical and clinical studies of MSCs.

Unlike in vitro studies that have clearly demonstrated MSCs' immunosuppressive effects against allogeneic $\mathrm{T}$ cell responses, in vivo studies have been more ambiguous. Pre-clinical studies revealed that various factors, including cell dose, timing of infusion, and pre-activated state of MSCs contribute to the therapeutic effects of MSCs. While some studies have suggested that MSCs can effectively treat GVHD in a dose-dependent manner (40, 41), others have shown that therapeutic effect could not be ob- 
Table 2. Discrepancy of mesenchymal stem cell therapy: expected versus actual results

\begin{tabular}{|c|c|c|c|}
\hline \multirow{2}{*}{$\begin{array}{l}\text { Target } \\
\text { disease }\end{array}$} & \multirow{2}{*}{ Expected results } & \multicolumn{2}{|c|}{ Actual results } \\
\hline & & Pre-clinical & Clinical \\
\hline GVHD & $\begin{array}{l}\text { Immunosuppressive effects against allo- } \\
\text { geneic responses based on in vitro } \\
\text { studies } \\
\text { Clinical efficacy based on Le Blanc's } \\
\text { study (36) }\end{array}$ & $\begin{array}{l}\text { Cell-dose, timing of infusion, and the } \\
\text { presence of IFN- } \gamma \text { levels affect the } \\
\text { therapeutic efficacy }\end{array}$ & $\begin{array}{l}\text { Clinical efficacy is limited to pediatric } \\
\text { patients with steroid-refractory acute } \\
\text { GVHD. } \\
\text { Efficacy depending on organ-involve- } \\
\text { ment is controversial. }\end{array}$ \\
\hline MI & $\begin{array}{l}\text { Cardiovascular regeneration and repair } \\
\text { of damaged myocardium } \\
\text { Immune modulation of inflammatory re- } \\
\text { sponse following } \mathrm{Ml} \text { through paracrine } \\
\text { factors }\end{array}$ & $\begin{array}{l}\text { MSC therapy showed overall positive } \\
\text { results } \\
\text { MSCs do not persist following admin- } \\
\text { istration indicating minimal possibility } \\
\text { for regeneration and tissue repair }\end{array}$ & $\begin{array}{l}\text { MSC therapy is well tolerated and safe, } \\
\text { with positive results during initial fol- } \\
\text { low-up } \\
\text { Efficacy do not persist at } 18 \text { months of } \\
\text { follow-up }\end{array}$ \\
\hline IBD & $\begin{array}{l}\text { Immune modulation of inflammatory re- } \\
\text { sponse present in gastrointestinal tract }\end{array}$ & $\begin{array}{l}\text { Mixed results: MSCs have produced } \\
\text { both positive negative results in IBD } \\
\text { Most studies focus on modification of } \\
\text { MSCs for treatment, rather than as sin- } \\
\text { gle agent }\end{array}$ & $\begin{array}{l}\text { Systemic infusion of MSCs show limited } \\
\text { clinical efficacy compared to intrale- } \\
\text { sional treatment }\end{array}$ \\
\hline MS & $\begin{array}{l}\text { Immune modulation that regulate effec- } \\
\text { tor cells involved in pathogenesis of } \\
\text { neurodegenerative diseases }\end{array}$ & $\begin{array}{l}\text { MSC therapy was only effective when } \\
\text { used at disease onset and not during } \\
\text { chronic phase of disease }\end{array}$ & $\begin{array}{l}\text { Limiting number of clinical trials, but } \\
\text { feasibility and safety has been reported } \\
\text { Mixed reports on clinical efficacy: im- } \\
\text { provements and deterioration were } \\
\text { both reported }\end{array}$ \\
\hline SLE & $\begin{array}{l}\text { Immune modulation of inflammatory re- } \\
\text { sponse involved in multiple organs }\end{array}$ & $\begin{array}{l}\text { Allogeneic and umbilical cord blood de- } \\
\text { rived MSCs improve renal functions } \\
\text { but not anti-double stranded DNA an- } \\
\text { tibody production levels } \\
\text { Worsening of disease in one study was } \\
\text { also noted }\end{array}$ & $\begin{array}{l}\text { Allogeneic and umbilical cord-derived } \\
\text { MSCs show therapeutic efficacy, but }\end{array}$ \\
\hline RA & $\begin{array}{l}\text { Immune modulation of Th17-related in- } \\
\text { flammatory response }\end{array}$ & $\begin{array}{l}\text { Mixed results: aggravation of disease re- } \\
\text { gardless of timing of treatment was } \\
\text { noted. Positive effects of MSCs at the } \\
\text { time of } \mathrm{CIA} \text { induction prevented in- } \\
\text { cidence }\end{array}$ & $\begin{array}{l}\text { Only one report on MSC therapy for RA } \\
\text { demonstrating feasibility: } 6 \text { months fol- } \\
\text { low-up show improved clinical out- } \\
\text { come }\end{array}$ \\
\hline
\end{tabular}

CIA: collagen-induced arthritis; GVHD: graft-versus-host disease; IBD: inflammatory bowel disease; IFN: interferon; MI: myocardial infarction; MS: multiple sclerosis; MSC: mesenchymal stem cells; SLE: systemic lupus erythematosus; RA: rheumatoid arthritis.

tained at any dose (42-45). In addition to cell dose, studies proposed that the timing of treatment might play a more critical role in MSC-mediated immune suppression. Regarding the timing of administration, Polchert et al. revealed that MSCs were ineffective before GVHD development or when GVHD was too severe. This study attributed the inconsistency of MSC treatment to the difference in IFN- $\gamma$ levels at different time points of GVHD development (43). Thl cytokine, IFN- $\gamma$ play a pivotal role in the immunomodulatory function of MSCs. MSCs pretreated with IFN- $\gamma$ could prevent GVHD even when administered at the time of transplantation. Nonetheless, several pre-clinical studies failed to exhibit therapeutic potential of MSCs regardless of various timing and dose $(2,44,46)$.

With the dramatic outcome of the first GVHD patient treated with MSCs, MSC therapy has undoubtedly showed promising results for the treatment of GVHD. In Ringden's subsequent study (47), MSCs administered in patients with grades III to IV steroid-refractory GVHD showed a complete remission rate of $75 \%$. The European Group for Blood and Marrow Transplantation obtained similar results in a multicenter phase II study using allogeneic and third-party bone marrow derived MSCs (48). Patients with steroid-refractory GVHD were treated with MSCs from various donor sources and had a significantly reduced level or transplantation-related mortality. While the small sample size and heterogeneous treatment protocols and MSC products limit the characterization of MSC efficacy, it is becoming clear that MSC therapy may be more effective in specific environments indicating that mixed results 
of MSCs for GVHD may arise depending on age, organ involvement, and severity of GVHD patients. In a multicenter trial, a greater proportion of pediatric patients responded to MSCs than adults (48). Furthermore, patients with skin-involved GVHD generally had a higher response rate to MSC treatment (49-51) whereas some studies have suggested that gastrointestinal GVHD may respond better $(52,53)$. In addition, studies that included both acute and chronic GVHD patients, the response was higher in acute GVHD $(49,51)$. It is important to recognize, however, that there is generally a lack of studies on de novo GVHD, chronic GVHD, and GVHD prophylaxis. Majority of studies involved patients resistant to conventional steroids and failed at least their first-line of treatment $(13,25,43,50$, $54,55)$ suggesting a better outcome in these settings. In contrast, there is some evidence that MSCs may be less effective in cGVHD (31) and GVHD prophylaxis (50).

Despite these potential variables in identifying optimal clinical settings for MSC therapy, the efficacy of MSCs is still unpredictable. In the phase III industry-sponsored trial (NCT00366145) using Prochymal for the treatment of steroid-refractory GVHD, public reports announced that Prochymal failed to achieve increased complete response rate compared to placebo controls $(39,52)$.

\section{Myocardial Inflammation}

Despite rapid medical advancements in the cardiovascular field, inflammatory reactions that occur upon heart diseases and failures continue to be associated high morbidity and mortality rates. Initially, MSCs were used following myocardial infarction due to their regenerative and tissue repair properties. Pre-clinical studies focused on the evaluation of MSC therapy through the measure of cardiac function and effects on cardiac remodeling (56-58). However, with the discovery that only a small portion of the injected MSCs remained present in the heart $(59,60)$, interest shifted toward MSC-produced paracrine factors as a critical role post myocardial infarction $(61,62)$. Despite different reported mechanisms of actions, MSC therapy in cardiovascular diseases of animal models have showed overall positive results.

In a pilot clinical trial, patients with acute myocardial infarction received intracoronary injection of autologous MSCs compared to saline (63). The administration of MSCs showed significant clinical improvement compared to the control group. Through cardiac electromechanical mapping, Chen et al. were able to detect viable MSCs up to three months after infusion and increased cardiac functions as demonstrated by cardiac echocardiography. Since then, further clinical trials attempted to assess the safety and efficacy of MSC transplantation for the treatment of cardiovascular diseases, including myocardial infarction and chronic ischemic cardiomyopathy (64-69). Similar to GVHD trials, the heterogeneity of clinical protocols has limited the direct comparison of MSC efficacy in cardiovascular diseases.

The different administration routes by MSC therapy may especially affect the outcomes of cardiovascular diseases. The delivery methods of MSCs include percutaneous coronary intervention, intracoronary injection, intramyocardial injection, and intravenous injection. However, direct comparison between the administration routes and following clinical outcomes is not available. There is evidence, however, that the intracoronary delivery may cause microinfarction by microvascular obstruction (70) or undesired tissue differentiation, such as bone, in the myocardium (71). Interestingly, the intravenous injection of MSCs in the randomized placebo-controlled dose-escalating trial by Osiris Therapeutics, led to an improved clinical outcome compared to the placebo group (65). However, in this study, 6-months follow-up was too short to evaluate the role of MSC in the recovery of cardiac function. Similarly, patients receiving intracoronary injection of MSCs initially showed significant improvement in left ventricular ejection compared control; however this difference did not last up to 18 months (38). Therefore, while both direct and systemic infusions of MSCs are clinically feasible for cardiovascular diseases, the efficacy of MSCs remains to be elucidated due to limited follow-up.

\section{Crohn's Disease}

Crohn's disease, also referred to as inflammatory bowel's disease (IBD), is a chronic inflammatory autoimmune disease in which the immune system attacks the gastrointestinal tract. In pre-clinical studies, MSCs were hypothesized to exert immunomodulatory effects that would improve the pathogenesis of IBD. Previously, we reported for the first time that MSCs are not clinically beneficial in IBD treatment (72). Other pre-clinical studies have suggested the positive outcomes of MSCs for the treatment of IBD; however, in these studies, MSCs were not used alone, but rather genetically modified to IL-12p40 (73), coated with antibodies (74), or genetically depleted with autoimmune regulators (75). In a single study that did claim the positive effects of MSCs, improved clinical IBD score consisting of weight loss, stool consistency and stool bleeding were noted but immune modulation of inflammatory cytokines was not described (76).

In contrast to the clinical application of MSCs for other diseases, the use of MSCs for IBD treatment demonstrates 
the most homogeneity in the source of MSCs and administration protocols. Majority of trials used either allogeneic (77-82) of autologous MSCs (83) derived from adipose tissue; however, the use of bone-marrow derived MSCs has also been reported $(84,85)$. Furthermore, majority of clinical trials used direct intralesional infusion of MSCs mixed with fibrin glue (77-84) whereas only a single study reported the intravenous injection of MSCs (85). While MSC therapy showed local healing of Crohn's fistula through intralesional infusions, the efficacy of MSC therapy in refractory IBD patients treated with systemic infusions is ambiguous. Only a small portion of patients showed clinical response six weeks post-treatment (85). The observations that intralesional treatment of MSCs mainly improved local symptoms rather than the basic pathogenesis itself support the notion that the systemic delivery of MSCs may not be efficacious indicating the important discrepancy of MSC therapy based on administration routes.

\section{Multiple Sclerosis}

In addition to Crohn's disease, MSCs for the treatment of autoimmune diseases in various animal models, such as experimental autoimmune encephalomyelitis, systemic lupus erythematosus (SLE), and rheumatoid arthritis (RA) have been reported. Multiple sclerosis is a chronic inflammatory demyelinating disease of the central nervous system. Initially, the therapeutic potential of MSCs have been implicated in neurodegenerative diseases of the central nervous system including stroke (86), Parkinson's disease (87), and spinal cord injury (88). Although the precise mechanisms of MSCs were not understood at the time, it was hypothesized that the immunomodulatory effects of MSCs could regulate various effector cells involved in the pathogenesis of neurodegenerative diseases. In experimental autoimmune encephalomyelitis, a model for multiple sclerosis, the intravenous administration of MSCs induced tolerance to myelin oligodendrocyte glycoprotein promoting improvement in clinical symptoms associated with the reduction of demyelination and CNS infiltration by lymphocytes (89). However, MSC therapy was only effective when used at disease onset or at the peak point during inflammation; however, not during chronic phase. Therefore, MSCs may be highly dependent on the timing of administration in multiple sclerosis, as in GVHD.

Clinical studies on MSCs for multiple sclerosis are limiting. The intrathecal administrations of autologous MSCs for these patients were feasible and safe; however, the clinical results remain unclear. While clinical im- provements associated with reduced expanded disability status scale were reported in some patients, others showed no improvement or worsening of diseases (90-92). However, limited studies and small sample size prevent definitive conclusions on the effects of MSC therapy for multiple sclerosis.

\section{Systemic Lupus Erythematosus (SLE)}

Next, SLE is an autoimmune inflammatory disease with multi-organ involvement including the kidney, brain, lung, and hematopoietic systems. It has been previous suggested in both mice (93) and humans (94) that MSCs derived from the diseased individuals have abnormalities in terms of phenotype, proliferation, and differentiation. The transplantation of MSCs from healthy donors, however, was able to ameliorate the disorder (93). These observations support the use of allogeneic, rather than autologous, MSCs for SLE. In murine models, allogeneic MSCs or xenogeneic human cord-blood derived MSCs for the treatment of SLE. However, the results have not been consistent. While both human and allogeneic murine MSCs were able to alleviate renal functions associated with SLE (95), other clinical symptoms including proteinuria or double-stranded DNA levels remained unchanged (19). Furthermore, allogeneic MSCs could also enhance anti-double stranded DNA antibody production levels and worsen the disease (96).

Similarly, in the clinical setting, the use of allogeneic and umbilical cord-derived MSCs have shown therapeutic potential in active SLE patients correlated with ameliorated disease activity, improved serological markers, and stabilized renal functions (93). Furthermore, MSC therapy was feasible in patients with refractory $\operatorname{SLE}(97,98)$. The results of these initial clinical trials are encouraging; however, the absence of larger randomized controlled clinical trials for SLE and other autoimmune diseases need to be resolved for further analysis.

\section{Rheumatoid Arthritis (RA)}

$\mathrm{RA}$ is a T-cell-mediated autoimmune disease characterized by cartilage and bone destruction. Despite continued research on the role of MSCs in RA, therapeutic potential of MSCs is controversial. In our study, we observed that MSCs are ineffective for treatment of collagen-induced arthritis (CIA), a murine model for rheumatoid arthritis, promoting Th17 related cytokines and subsequently aggravating symptoms of CIA (99). In another study, the negative effects of MSCs in CIA were associated with the presence of TNF-a, which reversed the immunomodulatory properties of MSCs and worsened clin- 
ical symptoms (100). Various doses were injected at the time of immunization or booster injection; however, the aggravation of clinical symptoms was similar in both conditions. In contrast, therapeutic effects have also been demonstrated (100). A single injection of MSCs at the time of CIA induction could prevent the incidence of CIA. Interestingly, MSC treatment following the establishment of CIA could also prevent the exacerbation of disease in which 7 of 10 animals treated with MSCs showed significantly lower disease score (101).

The mixed results demonstrated in pre-clinical studies have delayed the application of MSCs for RA treatment in clinical trials. The use of MSCs in RA patients had not been reported in the clinic until recently. In 2013, Wang et al. reported the safety and efficacy of umbilical cord derived MSCs in the treatment of RA (102). In the ongoing cohort, 172 patients with active RA refractory to traditional treatments were allocated into two groups, in which patients received anti-rheumatic medication with or without MSCs. MSC therapy in RA were safe and effective in controlling the refractory disease. In MSCs-treated groups, improvements of clinical manifestations correlated with decreased levels of inflammatory cytokine and increased percentages of regulatory $T$ cells. The clinical benefits were persistent up to 6 months with a single infusion and repeated infusions could be tolerated and further enhanced efficacy. Thus, in contrast to animal models, MSCs may provide significant benefits for RA.

\section{Limitations of MSCs-based immune modulation}

Overall, previous studies described above have demonstrated the feasibility and safety of MSCs. However, the discrepancies regarding therapeutic efficacy for most diseases have dampened the initial enthusiasm and optimism for MSC therapy. The causes for these discrepancies could be countless. Recently, Galipeau presented a review article discussing the potential variables affecting MSC therapy in response to the discrepancy between the European multicenter GVHD trials and the Osiris sponsored trial. He focused mainly on the lack of standardized MSC products throughout industrial and academic centers, including donor variance, epigenetic reprogramming and senescence followed by culture expansion, immunogenicity induced during culture and cryopreservation (103). While the procedures involved in isolation, culture, expansion, and delivery of MSCs are critical, we believe that our attention must now shift toward the MSC-based immune modulation in different clinical settings and varying inflammatory environments. The source of MSCs may be critical in models such as SLE and optimal delivery route of MSC treatment may be important in cardiovascular diseases, Crohn's fistula and multiple sclerosis that involve local injection; however, ultimately, the fundamental therapeutic benefits of MSC therapy arise from their immunomodulatory properties and their capability to elicit these properties following administration.

The lessons we have learned from pre-clinical studies of MSC therapy is that MSCs are highly-dependent on the environmental inflammatory conditions. These observations highlight the inevitable limitation of MSC therapy for immune-mediated diseases. MSCs are not constitutively inhibitory, but require the "licensing" by acute inflammatory cytokines including IFN- $\gamma$, TNF, IL- $\alpha$ and/or IL-1 $\beta$ to acquire immunosuppressive effects (104). Treatment of MSCs with IFN- $\gamma$ induced increased secretion of chemokine receptor ligands ICAM-1, CXCL-10, and CCL-8 $(105,106)$, as well as increased production of immunosuppressive IDO (107). The role of IFN- $\gamma$ in MSC-mediated immune suppression was also demonstrated in vivo (43). When IFN- $\gamma$ knock-out mice were used as effectors of GVHD, MSCs were unable to improve the survival regardless of the time of treatment. In addition to inflammatory cytokines, immunosuppressive cytokines such as TGF- $\beta$ that exist in certain environments could modulate the capacities of MSCs. Interestingly, MSCs present receptors for TGF- $\beta$ and depending on the inflammatory conditions, TGF- $\beta$ can reverse the immunomodulatory effects of MSCs. In combination with IFN- $\gamma$ and TNF, MSCs may become less immunosuppressive (108). Moreover, the activation of Toll-like receptors (TLRs) present in MSCs, such as TLR3 and TLR4 can be activated to acquire distinct immunoregulatory functions (109). Therefore the understanding of the pathological processes involved in various diseases will be critical for appropriate clinical applications of MSCs.

Different states of inflammation can result in different responses to MSC treatment, which indicates the importance of timing of MSC administration. As described in pre-clinical GVHD model (43), a narrow window exists for MSC in which adequate levels of inflammatory IFN- $\gamma$ can license MSCs. This observation might partly explain the discrepancies in GVHD models. Furthermore, while Th1-related cytokines, such as IFN- $\gamma$, is dominant in GVHD, chronic inflammatory autoimmune diseases are characterized by up-regulated Th17 levels. The effects of Th17 response on MSCs are less clear as there is evidence that MSCs may promote the expansion of Th17 cells (110-112). In the presence of pro-inflammatory cytokines, such as IFN- $\gamma$ and TNF- $\alpha$, MSCs produce significant 
levels of IL- 6 in addition to TGF- $\beta$ and this combination of TGF- $\beta$ and IL- 6 can induce polarization of naive T cells into Th17 cells (113). On the other hand, IL-17 may be helpful in enhancing the immunosuppressive functions of MSCs, even in low IFN- $\gamma$ conditions (114). Therefore, understanding the role of Th17 cytokines on MSC-based immune modulation could provide important insights on clinical application of MSCs for autoimmune diseases including IBD, multiple sclerosis, SLE, and RA.

Furthermore, inflammatory conditions change throughout the course of pathogenesis and immune response, which may affect the plasticity of MSCs following administration. Therefore, understanding the biological fate of MSCs in vivo may be necessary. While the in vivo monitoring have been previously discussed to investigate the migratory functions and differentiation potential of MSCs (115), tracking the cell-distribution and the persistence of cells in vivo may indirectly address the interactions of MSCs with different cytokines depending on the location and the time-course following administration.

\section{Why we still need MSC therapy?}

Therapeutic efficacy and mechanisms of MSC therapy still remains to be elucidated. Nevertheless, MSCs are still an attractive alternative for the treatment of various diseases. First, MSCs have the ability to regenerate and differentiate into different cell lineages similar to that of embryonic stem cells. However, MSCs have several advantages over embryonic stem cells in that MSCs are free of ethical issues, have low immunogenicity and no teratoma risks. Second, MSCs can be easily propagated ex vivo from various sources including, bone marrow, adipose tissue, and umbilical cord blood to reach clinically relevant cell doses. Third, and most importantly, MSCs possess unique immunomodulatory and migratory features that make then attractive for treating various diseases. Despite mixed clinical outcomes and lack of established data on in vivo efficacy, evidence continues to suggest that, when exposed in an appropriate setting, MSCs have the potential to display a potent immunomodulatory effect. In addition, the concept that MSCs can be polarized by certain stimuli provides the potential for manipulating MSC to obtain more predictable clinical effects. Therefore, the current challenges and limitations of MSCs need to be addressed through extensive investigation of MSC based immune modulatory mechanisms and continued applications in animal models and clinical trials.

\section{A new paradigm for MSCs: enhancing MSC-based immune-modulation}

The understanding that MSCs are highly responsive to environmental stimuli provides a new guideline for both exogenous and endogenous modifications of future MSC therapies. Therefore, we suggest a new paradigm for MSC-based therapies that focuses on enhancement of MSC-based immune-modulation.

\section{Gene-modified MSCs}

Sustained expression of therapeutic genes through gene modification can significantly enhance the potency of MSCs independent of external inflammatory stimuli. IL-10 transduced MSCs have been used to treat GVHD (116). While untransduced MSCs were ineffective in suppressing the development of GVHD, IL-10 transduced MSCs significantly decreased mortality rates of mice, which correlated with decreased levels of pro-inflammatory cytokines. This clinical benefit also correlated with MSCs ability to deliver IL-10 to target inflammatory sites. Gene-modified MSCs have also been reported in various experimental autoimmune models. We have previously showed that MSCs transduced with TGF- $\beta$ could potently suppress CIA models compared to untransduced MSCs (99). IL-12p40 expressing MSCs could also ameliorate murine colitis compared to normal MSCs (46). Also, MSCs engineered to overexpress IL-4 could attenuate experimental autoimmune encephalomyelitis (117).

\section{Pre-activated MSCs}

However, genetically engineered MSCs have yet to be applied in the clinical setting for immune modulation. The use of genetically engineered MSC may raise critical safety issues for clinical application. In addition to genetic manipulation, the consistent secretion of anti-inflammatory cytokines may paradoxically cause pathological immune responses depending on the factors involved in disease progression. Therefore, efforts to transiently strengthen MSC-based immune modulation may be more clinically relevant.

The pre-treatment of IFN- $\gamma$ has been previously discussed in GVHD (43). Furthermore, pre-treatment of MSCs with growth factors, including fibroblast growth factor, insulin-like growth factor, bone morphogenetic protein and stem cell derived factors have been reported to enhance cell survival and cytoprotective effects of MSCs exposed to hostile environments of hypoxic myocardial ischemia $(118,119)$. Moreover, activation of nucleotide-binding oligomerization domain 2 expressed on human um- 
bilical cord-blood derived MSCs by muramyl dipeptide induces upregulation of PGE2 which significantly enhances the inhibition of mononuclear cell proliferation (120). NOD2 signaling could be useful in that it is specifically expressed on umbilical cord-blood derived MSCs rather than other cell sources.

\section{MSC-based combination cell therapy}

One of major mechanisms of MSC-based immune modulation is the induction of regulatory cell subsets including Tregs, both in vitro and in vivo (40, 121). Therefore, MSC-mediated immune modulation is interdependent on the presence of endogenous Tregs. We postulated that soluble factors secreted by MSCs can promote the induction of Treg differentiation, and in turn, the cytokines produced by Tregs can promote immunosuppressive potential of MSCs. The combination of two immunosuppressive cell types, MSCs and Tregs, could synergistically support their functions and stabilize their plasticity. Supporting this hypothesis, a study reported that MSCs and Tregs, in combination, do not impair each other's respective functions (122). In our study, we compared single cell therapy groups (MSCs or Tregs alone) with combined cell therapy group initially in an acute GVHD model (123). We observed that the combined-cell therapy approach had synergistic immunomodulatory effects in inducing long-term survival and reducing clinicopathological symptoms of GVHD which was associated with effective inhibition of both Thl and Th17 responses compared to MSCs-treated alone. In subsequent studies, we further investigated combined-cell therapy of MSCs and Tregs in other transplantation models, including the induction of mixed chimerism following nonmyeloablative allogeneic HSCT (124), and the prevention of allogeneic skin-graft rejection (125), and observed similar results.

\section{Identifying therapeutic windows between conventional therapies for MSC treatment}

Based on reported clinical studies, MSC therapy seems to be most effective in immunosuppressant-resistant conditions, while randomized studies involving immunosuppressant-sensitive patients did not show therapeutic efficacy. Conventional immunosuppressants used to treat immune-mediated disorders involve potent inhibition of inflammatory responses. Although additive effects of MSCs and immunosuppressants may be expected in theory, the administration of MSCs during the use of immunosuppressants such as cyclosporine A (126) and dextametasone (127) has shown to disable the immunomodulatory functions of MSCs. This suggests that sufficient levels of cyto- kines or various paracrine factors involved in the microenvironment may be required for supporting MSCs' functions. Therefore, either the application of MSCs in immunosuppressant-resistant patients or the timely administration of MSCs during periods of immunosuppressant tapering could be considered.

\section{Concluding remarks}

In conclusion, we are at a critical milestone of MSC therapy for application in immunological diseases. The results of many animal and clinical studies have revealed the limitations of MSCs for therapeutic use, but at the same time, these studies have addressed numerous underlying mechanisms of immune modulation illuminating the possibility for overcoming the current limitations of MSC therapy. Therefore, a shift in MSC therapy toward the focus on enhancing MSC-based immune modulation may allow MSC therapy to continue to advance forward in future studies.

\section{Acknowledgments}

This study was supported by a grant from the Korea Healthcare Technology R\&D project, Ministry for Health, Welfare, and Family Affairs, Republic of Korea: HI12C0193 (A120241), by a research fund of Seoul St. Mary's Hospital, The Catholic University of Korea and by a grant from Catholic Institute of Cell therapy.

\section{Potential conflict of interest}

The authors have no conflicting financial interest.

\section{References}

1. Dominici M, Le Blanc K, Mueller I, Slaper-Cortenbach I, Marini F, Krause D, Deans R, Keating A, Prockop Dj, Horwitz E. Minimal criteria for defining multipotent mesenchymal stromal cells. The International Society for Cellular Therapy position statement. Cytotherapy 2006;8: 315-317

2. Kim N, Cho SG. Clinical applications of mesenchymal stem cells. Korean J Intern Med 2013;28:387-402

3. Keating A. How do mesenchymal stromal cells suppress $T$ cells? Cell Stem Cell 2008;2:106-108

4. Sotiropoulou PA, Perez SA, Gritzapis AD, Baxevanis CN, Papamichail M. Interactions between human mesenchymal stem cells and natural killer cells. Stem Cells 2006;24:74-85

5. English K, Ryan JM, Tobin L, Murphy MJ, Barry FP, Mahon BP. Cell contact, prostaglandin E(2) and transforming growth factor beta 1 play non-redundant roles in human mesenchymal stem cell induction of CD4+CD25 (High) forkhead box P3 + regulatory $\mathrm{T}$ cells. Clin Exp 
Immunol 2009;156:149-160

6. Di Nicola M, Carlo-Stella C, Magni M, Milanesi M, Longoni PD, Matteucci P, Grisanti S, Gianni AM. Human bone marrow stromal cells suppress T-lymphocyte proliferation induced by cellular or nonspecific mitogenic stimuli. Blood 2002;99:3838-3843

7. Ren G, Zhang L, Zhao X, Xu G, Zhang Y, Roberts AI, Zhao RC, Shi Y. Mesenchymal stem cell-mediated immunosuppression occurs via concerted action of chemokines and nitric oxide. Cell Stem Cell 2008;2:141-150

8. Stagg J, Galipeau J. Mechanisms of immune modulation by mesenchymal stromal cells and clinical translation. Curr Mol Med 2013;13:856-867

9. Nauta AJ, Kruisselbrink AB, Lurvink E, Willemze R, Fibbe WE. Mesenchymal stem cells inhibit generation and function of both CD34+-derived and monocyte-derived dendritic cells. J Immunol 2006;177:2080-2087

10. English K, Barry FP, Mahon BP. Murine mesenchymal stem cells suppress dendritic cell migration, maturation and antigen presentation. Immunol Lett 2008;115:50-58

11. Djouad F, Charbonnier LM, Bouffi C, Louis-Plence P, Bony C, Apparailly F, Cantos C, Jorgensen C, Noël D. Mesenchymal stem cells inhibit the differentiation of dendritic cells through an interleukin-6-dependent mechanism. Stem Cells 2007;25:2025-2032

12. Spaggiari GM, Abdelrazik H, Becchetti F, Moretta L. MSCs inhibit monocyte-derived DC maturation and function by selectively interfering with the generation of immature DCs: central role of MSC-derived prostaglandin E2. Blood 2009;113:6576-6583

13. Li YP, Paczesny S, Lauret E, Poirault S, Bordigoni P, Mekhloufi F, Hequet O, Bertrand Y, Ou-Yang JP, Stoltz JF, Miossec P, Eljaafari A. Human mesenchymal stem cells license adult CD34+ hemopoietic progenitor cells to differentiate into regulatory dendritic cells through activation of the Notch pathway. J Immunol 2008;180:1598-1608

14. Németh K, Leelahavanichkul A, Yuen PS, Mayer B, Parmelee A, Doi K, Robey PG, Leelahavanichkul K, Koller BH, Brown JM, Hu X, Jelinek I, Star RA, Mezey E. Bone marrow stromal cells attenuate sepsis via prostaglandin $\mathrm{E}(2)$-dependent reprogramming of host macrophages to increase their interleukin-10 production. Nat Med 2009;15:42-49

15. Spaggiari GM, Capobianco A, Abdelrazik H, Becchetti F, Mingari MC, Moretta L. Mesenchymal stem cells inhibit natural killer-cell proliferation, cytotoxicity, and cytokine production: role of indoleamine 2,3-dioxygenase and prostaglandin E2. Blood 2008;111:1327-1333

16. Duffy MM, Pindjakova J, Hanley SA, McCarthy C, Weidhofer GA, Sweeney EM, English K, Shaw G, Murphy JM, Barry FP, Mahon BP, Belton O, Ceredig R, Griffin MD. Mesenchymal stem cell inhibition of T-helper 17 celldifferentiation is triggered by cell-cell contact and mediated by prostaglandin E2 via the EP4 receptor. Eur J Immunol 2011;41:2840-2851

17. Meisel R, Zibert A, Laryea M, Göbel U, Däubener W, Dilloo D. Human bone marrow stromal cells inhibit alloge- neic T-cell responses by indoleamine 2,3-dioxygenase-mediated tryptophan degradation. Blood 2004;103:4619-4621

18. Krampera M, Glennie S, Dyson J, Scott D, Laylor R, Simpson E, Dazzi F. Bone marrow mesenchymal stem cells inhibit the response of naive and memory antigen-specific T cells to their cognate peptide. Blood 2003;101:3722-3729

19. Schena F, Gambini C, Gregorio A, Mosconi M, Reverberi D, Gattorno M, Casazza S, Uccelli A, Moretta L, Martini A, Traggiai E. Interferon- $\gamma$-dependent inhibition of $\mathrm{B}$ cell activation by bone marrow-derived mesenchymal stem cells in a murine model of systemic lupus erythematosus. Arthritis Rheum 2010;62:2776-2786

20. Choi H, Lee RH, Bazhanov N, Oh JY, Prockop DJ. Anti-inflammatory protein TSG-6 secreted by activated MSCs attenuates zymosan-induced mouse peritonitis by decreasing TLR2/NF- $\kappa \mathrm{B}$ signaling in resident macrophages. Blood 2011;118:330-338

21. Maggini J, Mirkin G, Bognanni I, Holmberg J, Piazzón IM, Nepomnaschy I, Costa H, Cañones C, Raiden S, Vermeulen M, Geffner JR. Mouse bone marrow-derived mesenchymal stromal cells turn activated macrophages into a regulatorylike profile. PLoS One 2010;5:e9252

22. Kim J, Hematti P. Mesenchymal stem cell-educated macrophages: a novel type of alternatively activated macrophages. Exp Hematol 2009;37:1445-1453

23. Zhang B, Liu R, Shi D, Liu X, Chen Y, Dou X, Zhu X, Lu C, Liang W, Liao L, Zenke M, Zhao RC. Mesenchymal stem cells induce mature dendritic cells into a novel Jagged-2-dependent regulatory dendritic cell population. Blood 2009;113:46-57

24. Li Q, Fang Y, Li X, Zhang H, Liu M, Yang H, Kang Z, Li Y, Wang Y. Mechanism of the plant cytochrome P450 for herbicide resistance: a modelling study. J Enzyme Inhib Med Chem 2013;28:1182-1191

25. Liu X, Qu X, Chen Y, Liao L, Cheng K, Shao C, Zenke M, Keating A, Zhao RC. Mesenchymal stem/stromal cells induce the generation of novel IL-10-dependent regulatory dendritic cells by SOCS3 activation. J Immunol 2012;189: 1182-1192

26. Bai L, Lennon DP, Eaton V, Maier K, Caplan AI, Miller SD, Miller RH. Human bone marrow-derived mesenchymal stem cells induce Th2-polarized immune response and promote endogenous repair in animal models of multiple sclerosis. Glia 2009;57:1192-1203

27. Batten P, Sarathchandra P, Antoniw JW, Tay SS, Lowdell MW, Taylor PM, Yacoub MH. Human mesenchymal stem cells induce $\mathrm{T}$ cell anergy and downregulate $\mathrm{T}$ cell allo-responses via the TH2 pathway: relevance to tissue engineering human heart valves. Tissue Eng 2006;12:2263-2273

28. Ghannam S, Pène J, Moquet-Torcy G, Jorgensen C, Yssel H. Mesenchymal stem cells inhibit human Th17 cell differentiation and function and induce a $\mathrm{T}$ regulatory cell phenotype. J Immunol 2010;185:302-312

29. Maccario R, Podestà M, Moretta A, Cometa A, Comoli P, Montagna D, Daudt L, Ibatici A, Piaggio G, Pozzi S, Frassoni F, Locatelli F. Interaction of human mesenchymal 
stem cells with cells involved in alloantigen-specific immune response favors the differentiation of CD4+ T-cell subsets expressing a regulatory/suppressive phenotype. Haematologica 2005;90:516-525

30. Franquesa M, Hoogduijn MJ, Bestard O, Grinyó JM. Immunomodulatory effect of mesenchymal stem cells on B cells. Front Immunol 2012;3:212

31. Corcione A, Benvenuto F, Ferretti E, Giunti D, Cappiello V, Cazzanti F, Risso M, Gualandi F, Mancardi GL, Pistoia V, Uccelli A. Human mesenchymal stem cells modulate B-cell functions. Blood 2006;107:367-372

32. Comoli P, Ginevri F, Maccario R, Avanzini MA, Marconi M, Groff A, Cometa A, Cioni M, Porretti L, Barberi W, Frassoni F, Locatelli F. Human mesenchymal stem cells inhibit antibody production induced in vitro by allostimulation. Nephrol Dial Transplant 2008;23:1196-1202

33. Rasmusson I, Le Blanc K, Sundberg B, Ringdén O. Mesenchymal stem cells stimulate antibody secretion in human B cells. Scand J Immunol 2007;65:336-343

34. Traggiai E, Volpi S, Schena F, Gattorno M, Ferlito F, Moretta L, Martini A. Bone marrow-derived mesenchymal stem cells induce both polyclonal expansion and differentiation of B cells isolated from healthy donors and systemic lupus erythematosus patients. Stem Cells 2008;26: 562-569

35. Bartholomew A, Sturgeon C, Siatskas M, Ferrer K, McIntosh K, Patil S, Hardy W, Devine S, Ucker D, Deans R, Moseley A, Hoffman R. Mesenchymal stem cells suppress lymphocyte proliferation in vitro and prolong skin graft survival in vivo. Exp Hematol 2002;30:42-48

36. Le Blanc K, Rasmusson I, Sundberg B, Götherström C, Hassan $M$, Uzunel $M$, Ringdén $O$. Treatment of severe acute graft-versus-host disease with third party haploidentical mesenchymal stem cells. Lancet 2004;363:1439-1441

37. Wohn DY. Korea okays stem cell therapies despite limited peer-reviewed data. Nat Med 2012;18:329

38. Meyer GP, Wollert KC, Lotz J, Steffens J, Lippolt P, Fichtner S, Hecker H, Schaefer A, Arseniev L, Hertenstein B, Ganser A, Drexler H. Intracoronary bone marrow cell transfer after myocardial infarction: eighteen months' follow-up data from the randomized, controlled BOOST (BOne marrOw transfer to enhance ST-elevation infarct regeneration) trial. Circulation 2006;113:1287-1294

39. Allison M. Genzyme backs Osiris, despite Prochymal flop. Nat Biotechnol 2009;27:966-967

40. Joo SY, Cho KA, Jung YJ, Kim HS, Park SY, Choi YB, Hong KM, Woo SY, Seoh JY, Cho SJ, Ryu KH. Mesenchymal stromal cells inhibit graft-versus-host disease of mice in a dose-dependent manner. Cytotherapy 2010;12:361-370

41. Li H, Guo Z, Jiang X, Zhu H, Li X, Mao N. Mesenchymal stem cells alter migratory property of $\mathrm{T}$ and dendritic cells to delay the development of murine lethal acute graft-versus-host disease. Stem Cells 2008;26:2531-2541

42. Badillo AT, Peranteau WH, Heaton TE, Quinn C, Flake AW. Murine bone marrow derived stromal progenitor cells fail to prevent or treat acute graft-versus-host disease. $\mathrm{Br}$
J Haematol 2008;141:224-234

43. Polchert D, Sobinsky J, Douglas G, Kidd M, Moadsiri A, Reina E, Genrich K, Mehrotra S, Setty S, Smith B, Bartholomew A. IFN-gamma activation of mesenchymal stem cells for treatment and prevention of graft versus host disease. Eur J Immunol 2008;38:1745-1755

44. Sudres M, Norol F, Trenado A, Grégoire S, Charlotte F, Levacher B, Lataillade JJ, Bourin P, Holy X, Vernant JP, Klatzmann D, Cohen JL. Bone marrow mesenchymal stem cells suppress lymphocyte proliferation in vitro but fail to prevent graft-versus-host disease in mice. J Immunol 2006;176:7761-7767

45. Tisato V, Naresh K, Girdlestone J, Navarrete C, Dazzi F. Mesenchymal stem cells of cord blood origin are effective at preventing but not treating graft-versus-host disease. Leukemia 2007;21:1992-1999

46. Prigozhina TB, Khitrin S, Elkin G, Eizik O, Morecki S, Slavin S. Mesenchymal stromal cells lose their immunosuppressive potential after allotransplantation. Exp Hematol 2008;36:1370-1376

47. Ringdén O, Uzunel M, Rasmusson I, Remberger M, Sundberg B, Lönnies H, Marschall HU, Dlugosz A, Szakos A, Hassan Z, Omazic B, Aschan J, Barkholt L, Le Blanc $\mathrm{K}$. Mesenchymal stem cells for treatment of therapy-resistant graft-versus-host disease. Transplantation 2006;81: 1390-1397

48. Le Blanc K, Frassoni F, Ball L, Locatelli F, Roelofs H, Lewis I, Lanino E, Sundberg B, Bernardo ME, Remberger M, Dini G, Egeler RM, Bacigalupo A, Fibbe W, Ringdén O; Developmental Committee of the European Group for Blood and Marrow Transplantation. Mesenchymal stem cells for treatment of steroid-resistant, severe, acute graftversus-host disease: a phase II study. Lancet 2008;371: 1579-1586

49. Lucchini G, Introna M, Dander E, Rovelli A, Balduzzi A, Bonanomi S, Salvadè A, Capelli C, Belotti D, Gaipa G, Perseghin P, Vinci P, Lanino E, Chiusolo P, Orofino MG, Marktel S, Golay J, Rambaldi A, Biondi A, D'Amico G, Biagi E. Platelet-lysate-expanded mesenchymal stromal cells as a salvage therapy for severe resistant graft-versus-host disease in a pediatric population. Biol Blood Marrow Transplant 2010;16:1293-1301

50. von Bonin M, Stölzel F, Goedecke A, Richter K, Wuschek N, Hölig K, Platzbecker U, Illmer T, Schaich M, Schetelig J, Kiani A, Ordemann R, Ehninger G, Schmitz M, Bornhäuser $M$. Treatment of refractory acute GVHD with third-party MSC expanded in platelet lysate-containing medium. Bone Marrow Transplant 2009;43:245-251

51. Müller I, Kordowich S, Holzwarth C, Isensee G, Lang P, Neunhoeffer F, Dominici M, Greil J, Handgretinger R. Application of multipotent mesenchymal stromal cells in pediatric patients following allogeneic stem cell transplantation. Blood Cells Mol Dis 2008;40:25-32

52. Martin PJ, Uberti JP, Soiffer RJ, Klingemann H, Waller EK, Daly AS, Herrmann RP, Kebriaei P. Prochymal Improves response rates in patients with steroid-refractory 
acute graft versus host disease (SR-GVHD) involving the liver and gut: results of a randomized, placebo-controlled, multicenter phase III trial in GVHD. Biology of Blood and Marrow Transplant 2010;16 Suppl 2:S169-S170

53. Resnick IB, Barkats C, Shapira MY, Stepensky P, Bloom AI, Shimoni A, Mankuta D, Varda-Bloom N, Rheingold L, Yeshurun M, Bielorai B, Toren A, Zuckerman T, Nagler A, Or R. Treatment of severe steroid resistant acute GVHD with mesenchymal stromal cells (MSC). Am J Blood Res 2013;3:225-238

54. Fang B, Song YP, Liao LM, Han Q, Zhao RC. Treatment of severe therapy-resistant acute graft-versus-host disease with human adipose tissue-derived mesenchymal stem cells. Bone Marrow Transplant 2006;38:389-390

55. Wu KH, Chan CK, Tsai C, Chang YH, Sieber M, Chiu TH, Ho M, Peng CT, Wu HP, Huang JL. Effective treatment of severe steroid-resistant acute graft-versus-host disease with umbilical cord-derived mesenchymal stem cells. Transplantation 2011;91:1412-1416

56. Zhang S, Ge J, Sun A, Xu D, Qian J, Lin J, Zhao Y, Hu $\mathrm{H}$, Li Y, Wang K, Zou Y. Comparison of various kinds of bone marrow stem cells for the repair of infarcted myocardium: single clonally purified non-hematopoietic mesenchymal stem cells serve as a superior source. J Cell Biochem 2006;99:1132-1147

57. Nagaya N, Kangawa K, Itoh T, Iwase T, Murakami S, Miyahara Y, Fujii T, Uematsu $M$, Ohgushi H, Yamagishi M, Tokudome T, Mori H, Miyatake K, Kitamura S. Transplantation of mesenchymal stem cells improves cardiac function in a rat model of dilated cardiomyopathy. Circulation 2005;112:1128-1135

58. Schuleri KH, Feigenbaum GS, Centola M, Weiss ES, Zimmet JM, Turney J, Kellner J, Zviman MM, Hatzistergos KE, Detrick B, Conte JV, McNiece I, Steenbergen C, Lardo AC, Hare JM. Autologous mesenchymal stem cells produce reverse remodelling in chronic ischaemic cardiomyopathy. Eur Heart J 2009;30:2722-2732

59. Miyahara Y, Nagaya N, Kataoka M, Yanagawa B, Tanaka K, Hao H, Ishino K, Ishida H, Shimizu T, Kangawa K, Sano S, Okano T, Kitamura S, Mori H. Monolayered mesenchymal stem cells repair scarred myocardium after myocardial infarction. Nat Med 2006;12:459-465

60. Amado LC, Saliaris AP, Schuleri KH, St John M, Xie JS, Cattaneo S, Durand DJ, Fitton T, Kuang JQ, Stewart G, Lehrke S, Baumgartner WW, Martin BJ, Heldman AW, Hare JM. Cardiac repair with intramyocardial injection of allogeneic mesenchymal stem cells after myocardial infarction. Proc Natl Acad Sci U S A 2005;102:11474-11479

61. Caplan AI, Dennis JE. Mesenchymal stem cells as trophic mediators. J Cell Biochem 2006;98:1076-1084

62. Gnecchi $M, H e H$, Noiseux $N$, Liang OD, Zhang L, Morello F, Mu H, Melo LG, Pratt RE, Ingwall JS, Dzau VJ. Evidence supporting paracrine hypothesis for Aktmodified mesenchymal stem cell-mediated cardiac protection and functional improvement. FASEB J 2006;20: 661-669
63. Chen SL, Fang WW, Ye F, Liu YH, Qian J, Shan SJ, Zhang JJ, Chunhua RZ, Liao LM, Lin S, Sun JP. Effect on left ventricular function of intracoronary transplantation of autologous bone marrow mesenchymal stem cell in patients with acute myocardial infarction. Am J Cardiol 2004;94:92-95

64. Katritsis DG, Sotiropoulou PA, Karvouni E, Karabinos I, Korovesis S, Perez SA, Voridis EM, Papamichail M. Transcoronary transplantation of autologous mesenchymal stem cells and endothelial progenitors into infarcted human myocardium. Catheter Cardiovasc Interv 2005;65:321-329

65. Hare JM, Traverse JH, Henry TD, Dib N, Strumpf RK, Schulman SP, Gerstenblith G, DeMaria AN, Denktas AE, Gammon RS, Hermiller JB Jr, Reisman MA, Schaer GL, Sherman W. A randomized, double-blind, placebo-controlled, dose-escalation study of intravenous adult human mesenchymal stem cells (prochymal) after acute myocardial infarction. J Am Coll Cardiol 2009;54:2277-2286

66. Katritsis DG, Sotiropoulou P, Giazitzoglou E, Karvouni E, Papamichail M. Electrophysiological effects of intracoronary transplantation of autologous mesenchymal and endothelial progenitor cells. Europace 2007;9:167-171

67. Mohyeddin-Bonab M, Mohamad-Hassani MR, Alimoghaddam K, Sanatkar M, Gasemi M, Mirkhani H, Radmehr H, Salehi M, Eslami M, Farhig-Parsa A, Emami-Razavi H, Alemohammad MG, Solimani AA, Ghavamzadeh A, Nikbin B. Autologous in vitro expanded mesenchymal stem cell therapy for human old myocardial infarction. Arch Iran Med 2007;10:467-473

68. Ripa RS, Haack-Sørensen M, Wang Y, Jørgensen E, Mortensen S, Bindslev L, Friis T, Kastrup J. Bone marrow derived mesenchymal cell mobilization by granulocyte-colony stimulating factor after acute myocardial infarction: results from the Stem Cells in Myocardial Infarction (STEMMI) trial. Circulation 2007;116(11 Suppl):I24-I30

69. Chen S, Liu Z, Tian N, Zhang J, Yei F, Duan B, Zhu Z, Lin S, Kwan TW. Intracoronary transplantation of autologous bone marrow mesenchymal stem cells for ischemic cardiomyopathy due to isolated chronic occluded left anterior descending artery. J Invasive Cardiol 2006;18:552-556

70. Vulliet PR, Greeley M, Halloran SM, MacDonald KA, Kittleson MD. Intra-coronary arterial injection of mesenchymal stromal cells and microinfarction in dogs. Lancet 2004;363:783-784

71. Breitbach M, Bostani T, Roell W, Xia Y, Dewald O, Nygren JM, Fries JW, Tiemann K, Bohlen H, Hescheler J, Welz A, Bloch W, Jacobsen SE, Fleischmann BK. Potential risks of bone marrow cell transplantation into infarcted hearts. Blood 2007;110:1362-1369

72. Nam YS, Kim N, Im KI, Lim JY, Lee ES, Cho SG. Negative impact of bone-marrow-derived mesenchymal stem cells on dextran sulfate sodium-induced colitis. World J Gastroenterol 2015;21:2030-2039

73. Kim DJ, Kim KS, Song MY, Seo SH, Kim SJ, Yang BG, Jang $\mathrm{MH}$, Sung YC. Delivery of IL-12p40 ameliorates DSS-induced colitis by suppressing IL-17A expression and inflammation in the intestinal mucosa. Clin Immunol 


\section{2;144:190-199}

74. Ko IK, Kim BG, Awadallah A, Mikulan J, Lin P, Letterio JJ, Dennis JE. Targeting improves MSC treatment of inflammatory bowel disease. Mol Ther 2010;18:1365-1372

75. Parekkadan B, Fletcher AL, Li M, Tjota MY, BellemarePelletier A, Milwid JM, Lee JW, Yarmush ML, Turley SJ. Aire controls mesenchymal stem cell-mediated suppression in chronic colitis. Mol Ther 2012;20:178-186

76. He XW, He XS, Lian L, Wu XJ, Lan P. Systemic infusion of bone marrow-derived mesenchymal stem cells for treatment of experimental colitis in mice. Dig Dis Sci 2012;57: 3136-3144

77. de la Portilla F, Alba F, García-Olmo D, Herrerías JM, González FX, Galindo A. Expanded allogeneic adipose- derived stem cells (eASCs) for the treatment of complex perianal fistula in Crohn's disease: results from a multicenter phase I/IIa clinical trial. Int J Colorectal Dis 2013;28: 313-323

78. Lee WY, Park KJ, Cho YB, Yoon SN, Song KH, Kim do S, Jung SH, Kim M, Yoo HW, Kim I, Ha H, Yu CS. Autologous adipose tissue-derived stem cells treatment demonstrated favorable and sustainable therapeutic effect for Crohn's fistula. Stem Cells 2013;31:2575-2581

79. Cho YB, Lee WY, Park KJ, Kim M, Yoo HW, Yu CS. Autologous adipose tissue-derived stem cells for the treatment of Crohn's fistula: a phase I clinical study. Cell Transplant 2013;22:279-285

80. Herreros MD, Garcia-Arranz M, Guadalajara H, De-LaQuintana P, Garcia-Olmo D; FATT Collaborative Group. Autologous expanded adipose-derived stem cells for the treatment of complex cryptoglandular perianal fistulas: a phase III randomized clinical trial (FATT 1: fistula Advanced Therapy Trial 1) and long-term evaluation. Dis Colon Rectum 2012;55:762-772

81. Guadalajara H, Herreros D, De-La-Quintana P, Trebol J, Garcia-Arranz M, Garcia-Olmo D. Long-term follow-up of patients undergoing adipose-derived adult stem cell administration to treat complex perianal fistulas. Int J Colorectal Dis 2012;27:595-600

82. García-Olmo D, García-Arranz M, Herreros D, Pascual I, Peiro C, Rodríguez-Montes JA. A phase I clinical trial of the treatment of Crohn's fistula by adipose mesenchymal stem cell transplantation. Dis Colon Rectum 2005;48: 1416-1423

83. Garcia-Olmo D, Herreros D, Pascual I, Pascual JA, Del-Valle E, Zorrilla J, De-La-Quintana P, Garcia-Arranz $M$, Pascual M. Expanded adipose-derived stem cells for the treatment of complex perianal fistula: a phase II clinical trial. Dis Colon Rectum 2009;52:79-86

84. Ciccocioppo R, Bernardo ME, Sgarella A, Maccario R, Avanzini MA, Ubezio C, Minelli A, Alvisi C, Vanoli A, Calliada F, Dionigi P, Perotti C, Locatelli F, Corazza GR. Autologous bone marrow-derived mesenchymal stromal cells in the treatment of fistulising Crohn's disease. Gut 2011;60:788-798

85. Duijvestein $M$, Vos AC, Roelofs $H$, Wildenberg ME,
Wendrich BB, Verspaget HW, Kooy-Winkelaar EM, Koning F, Zwaginga JJ, Fidder HH, Verhaar AP, Fibbe WE, van den Brink GR, Hommes DW. Autologous bone marrow-derived mesenchymal stromal cell treatment for refractory luminal Crohn's disease: results of a phase I study. Gut 2010;59:1662-1669

86. Li Y, Chen J, Chen XG, Wang L, Gautam SC, Xu YX, Katakowski M, Zhang LJ, Lu M, Janakiraman N, Chopp $M$. Human marrow stromal cell therapy for stroke in rat: neurotrophins and functional recovery. Neurology 2002;59: 514-523

87. Park HJ, Lee PH, Bang OY, Lee G, Ahn YH. Mesenchymal stem cells therapy exerts neuroprotection in a progressive animal model of Parkinson's disease. J Neurochem 2008; 107:141-151

88. Akiyama Y, Radtke C, Kocsis JD. Remyelination of the rat spinal cord by transplantation of identified bone marrow stromal cells. J Neurosci 2002;22:6623-6630

89. Zappia E, Casazza S, Pedemonte E, Benvenuto F, Bonanni I, Gerdoni E, Giunti D, Ceravolo A, Cazzanti F, Frassoni F, Mancardi G, Uccelli A. Mesenchymal stem cells ameliorate experimental autoimmune encephalomyelitis inducing T-cell anergy. Blood 2005;106:1755-1761

90. Mohyeddin Bonab M, Yazdanbakhsh S, Lotfi J, Alimoghaddom K, Talebian F, Hooshmand F, Ghavamzadeh A, Nikbin B. Does mesenchymal stem cell therapy help multiple sclerosis patients? Report of a pilot study. Iran J Immunol 2007;4:50-57

91. Yamout B, Hourani R, Salti H, Barada W, El-Hajj T, Al-Kutoubi A, Herlopian A, Baz EK, Mahfouz R, KhalilHamdan R, Kreidieh NM, El-Sabban M, Bazarbachi A. Bone marrow mesenchymal stem cell transplantation in patients with multiple sclerosis: a pilot study. J Neuroimmunol 2010;227:185-189

92. Karussis D, Karageorgiou C, Vaknin-Dembinsky A, Gowda-Kurkalli B, Gomori JM, Kassis I, Bulte JW, Petrou P, Ben-Hur T, Abramsky O, Slavin S. Safety and immunological effects of mesenchymal stem cell transplantation in patients with multiple sclerosis and amyotrophic lateral sclerosis. Arch Neurol 2010;67:1187-1194

93. Sun L, Akiyama K, Zhang H, Yamaza T, Hou Y, Zhao S, $\mathrm{Xu} \mathrm{T}$, Le A, Shi S. Mesenchymal stem cell transplantation reverses multiorgan dysfunction in systemic lupus erythematosus mice and humans. Stem Cells 2009;27:1421-1432

94. Sun LY, Zhang HY, Feng XB, Hou YY, Lu LW, Fan LM. Abnormality of bone marrow-derived mesenchymal stem cells in patients with systemic lupus erythematosus. Lupus 2007;16:121-128

95. Chang JW, Hung SP, Wu HH, Wu WM, Yang AH, Tsai HL, Yang LY, Lee OK. Therapeutic effects of umbilical cord blood-derived mesenchymal stem cell transplantation in experimental lupus nephritis. Cell Transplant 2011;20: 245-257

96. Youd M, Blickarz C, Woodworth L, Touzjian T, Edling A, Tedstone J, Ruzek M, Tubo R, Kaplan J, Lodie T. Allogeneic mesenchymal stem cells do not protect NZBxNZW 
F1 mice from developing lupus disease. Clin Exp Immunol 2010;161:176-186

97. Liang J, Zhang H, Hua B, Wang H, Lu L, Shi S, Hou Y, Zeng X, Gilkeson GS, Sun L. Allogenic mesenchymal stem cells transplantation in refractory systemic lupus erythematosus: a pilot clinical study. Ann Rheum Dis 2010;69: 1423-1429

98. Sun L, Wang D, Liang J, Zhang H, Feng X, Wang H, Hua B, Liu B, Ye S, Hu X, Xu W, Zeng X, Hou Y, Gilkeson GS, Silver RM, Lu L, Shi S. Umbilical cord mesenchymal stem cell transplantation in severe and refractory systemic lupus erythematosus. Arthritis Rheum 2010;62:2467-2475

99. Park MJ, Park HS, Cho ML, Oh HJ, Cho YG, Min SY, Chung BH, Lee JW, Kim HY, Cho SG. Transforming growth factor $\beta$-transduced mesenchymal stem cells ameliorate experimental autoimmune arthritis through reciprocal regulation of Treg/Th17 cells and osteoclastogenesis. Arthritis Rheum 2011;63:1668-1680

100. Djouad F, Fritz V, Apparailly F, Louis-Plence P, Bony C, Sany J, Jorgensen C, Noël D. Reversal of the immunosuppressive properties of mesenchymal stem cells by tumor necrosis factor alpha in collagen-induced arthritis. Arthritis Rheum 2005;52:1595-1603

101. Augello A, Tasso R, Negrini SM, Cancedda R, Pennesi G. Cell therapy using allogeneic bone marrow mesenchymal stem cells prevents tissue damage in collagen-induced arthritis. Arthritis Rheum 2007;56:1175-1186

102. Wang L, Wang L, Cong X, Liu G, Zhou J, Bai B, Li Y, Bai W, Li M, Ji H, Zhu D, Wu M, Liu Y. Human umbilical cord mesenchymal stem cell therapy for patients with active rheumatoid arthritis: safety and efficacy. Stem Cells Dev 2013;22:3192-3202

103. Galipeau J. The mesenchymal stromal cells dilemma--does a negative phase III trial of random donor mesenchymal stromal cells in steroid-resistant graft-versus-host disease represent a death knell or a bump in the road? Cytotherapy 2013;15:2-8

104. Marigo I, Dazzi F. The immunomodulatory properties of mesenchymal stem cells. Semin Immunopathol 2011;33: 593-602

105. Krampera M, Cosmi L, Angeli R, Pasini A, Liotta F, Andreini A, Santarlasci V, Mazzinghi B, Pizzolo G, Vinante F, Romagnani P, Maggi E, Romagnani S, Annunziato F. Role for interferon-gamma in the immunomodulatory activity of human bone marrow mesenchymal stem cells. Stem Cells 2006;24:386-398

106. Dazzi F, Marelli-Berg FM. Mesenchymal stem cells for graft-versus-host disease: close encounters with T cells. Eur J Immunol 2008;38:1479-1482

107. Hoogduijn MJ, Popp F, Verbeek R, Masoodi M, Nicolaou A, Baan C, Dahlke MH. The immunomodulatory properties of mesenchymal stem cells and their use for immunotherapy. Int Immunopharmacol 2010;10:1496-1500

108. Xu C, Yu P, Han X, Du L, Gan J, Wang Y, Shi Y. TGF- $\beta$ promotes immune responses in the presence of mesenchymal stem cells. J Immunol 2014;192:103-109
109. Waterman RS, Tomchuck SL, Henkle SL, Betancourt AM. A new mesenchymal stem cell (MSC) paradigm: polarization into a pro-inflammatory MSC1 or an Immunosuppressive MSC2 phenotype. PLoS One 2010;5:e10088

110. Guo Z, Zheng C, Chen Z, Gu D, Du W, Ge J, Han Z, Yang R. Fetal BM-derived mesenchymal stem cells promote the expansion of human Th17 cells, but inhibit the production of Th1 cells. Eur J Immunol 2009;39:2840-2849

111. Eljaafari A, Tartelin ML, Aissaoui H, Chevrel G, Osta B, Lavocat F, Miossec P. Bone marrow-derived and synovium-derived mesenchymal cells promote Th17 cell expansion and activation through caspase 1 activation: contribution to the chronicity of rheumatoid arthritis. Arthritis Rheum 2012;64:2147-2157

112. Chen B, Hu J, Liao L, Sun Z, Han Q, Song Z, Zhao RC. Flk-1 + mesenchymal stem cells aggravate collagen-induced arthritis by up-regulating interleukin-6. Clin Exp Immunol 2010;159:292-302

113. Svobodova E, Krulova M, Zajicova A, Pokorna K, Prochazkova J, Trosan P, Holan V. The role of mouse mesenchymal stem cells in differentiation of naive T-cells into anti-inflammatory regulatory $\mathrm{T}$-cell or proinflammatory helper T-cell 17 population. Stem Cells Dev 2012;21:901-910

114. Han X, Yang Q, Lin L, Xu C, Zheng C, Chen X, Han Y, Li M, Cao W, Cao K, Chen Q, Xu G, Zhang Y, Zhang J, Schneider RJ, Qian Y, Wang Y, Brewer G, Shi Y. Interleukin-17 enhances immunosuppression by mesenchymal stem cells. Cell Death Differ 2014;21:1758-1768

115. Spaeth E, Klopp A, Dembinski J, Andreeff M, Marini F. Inflammation and tumor microenvironments: defining the migratory itinerary of mesenchymal stem cells. Gene Ther 2008;15:730-738

116. Min CK, Kim BG, Park G, Cho B, Oh IH. IL-10- transduced bone marrow mesenchymal stem cells can attenuate the severity of acute graft-versus-host disease after experimental allogeneic stem cell transplantation. Bone Marrow Transplant 2007;39:637-645

117. Payne NL, Dantanarayana A, Sun G, Moussa L, Caine S, McDonald C, Herszfeld D, Bernard CC, Siatskas C. Early intervention with gene-modified mesenchymal stem cells overexpressing interleukin-4 enhances anti-inflammatory responses and functional recovery in experimental autoimmune demyelination. Cell Adh Migr 2012;6:179-189

118. Hahn JY, Cho HJ, Kang HJ, Kim TS, Kim MH, Chung JH, Bae JW, Oh BH, Park YB, Kim HS. Pre-treatment of mesenchymal stem cells with a combination of growth factors enhances gap junction formation, cytoprotective effect on cardiomyocytes, and therapeutic efficacy for myocardial infarction. J Am Coll Cardiol 2008;51:933-943

119. Pasha Z, Wang Y, Sheikh R, Zhang D, Zhao T, Ashraf M. Preconditioning enhances cell survival and differentiation of stem cells during transplantation in infarcted myocardium. Cardiovasc Res 2008;77:134-142

120. Kim HS, Shin TH, Lee BC, Yu KR, Seo Y, Lee S, Seo MS, Hong IS, Choi SW, Seo KW, Núñez G, Park JH, Kang KS. Human umbilical cord blood mesenchymal stem cells re- 
duce colitis in mice by activating NOD2 signaling to COX2. Gastroenterology 2013;145:1392-1403 el-8

121. Burr SP, Dazzi F, Garden OA. Mesenchymal stromal cells and regulatory $T$ cells: the Yin and Yang of peripheral tolerance? Immunol Cell Biol 2013;91:12-18

122. Engela AU, Baan CC, Peeters AM, Weimar W, Hoogduijn MJ. Interaction between adipose tissue-derived mesenchymal stem cells and regulatory T-cells. Cell Transplant 2013;22:41-54

123. Lim JY, Park MJ, Im KI, Kim N, Jeon EJ, Kim EJ, Cho ML, Cho SG. Combination cell therapy using mesenchymal stem cells and regulatory T-cells provides a synergistic immunomodulatory effect associated with reciprocal regulation of TH1/TH2 and th17/treg cells in a murine acute graft-versus-host disease model. Cell Transplant 2014;23: 703-714

124. Im KI, Park MJ, Kim N, Lim JY, Park HS, Lee SH, Nam YS, Lee ES, Lee JH, Cho ML, Cho SG. Induction of mixed chimerism using combinatory cell-based immune modulation with mesenchymal stem cells and regulatory $\mathrm{T}$ cells for solid-organ transplant tolerance. Stem Cells Dev 2014;23:2364-2376

125. Lee JH, Jeon EJ, Kim N, Nam YS, Im KI, Lim JY, Kim EJ, Cho ML, Han KT, Cho SG. The synergistic immunoregulatory effects of culture-expanded mesenchymal stromal cells and CD4(+)25(+)Foxp3+ regulatory $\mathrm{T}$ cells on skin allograft rejection. PLoS One 2013;8:e70968

126. Inoue S, Popp FC, Koehl GE, Piso P, Schlitt HJ, Geissler EK, Dahlke MH. Immunomodulatory effects of mesenchymal stem cells in a rat organ transplant model. Transplantation 2006;81:1589-1595

127. Chen X, Gan Y, Li W, Su J, Zhang Y, Huang Y, Roberts AI, Han Y, Li J, Wang Y, Shi Y. The interaction between mesenchymal stem cells and steroids during inflammation. Cell Death Dis 2014;5:e1009 